\title{
Development of Zirconia Substituted 1393 Bioactive Glass for Orthopaedic Application
}

\author{
SANDEEP KUMARYADAV*, SARTHAK RAY, MD. ERSHAD, VIKASH KUMAR VYAS, \\ SUNIL PRASAD, AKHER ALI, SUSHMA YADAV, MANAS RANJAN MAJHI and RAM PYARE*
}

\author{
Department of Ceramic Engineering, Indian Institute of Technology (Banaras Hindu University), \\ Varanasi -221005, India. \\ ${ }^{\star}$ Corresponding author E-mail: sandeep.rs.cer.2006@gmail.com
}

http://dx.doi.org/10.13005/ojc/330605

(Received: August 13, 2017; Accepted: September 18, 2017)

\begin{abstract}
Zirconia was used as a bone substitute, since it has excellent mechanical properties. It is also good bioinert to bone tissue. In this study, we report on zirconia substituted 1393 bioactive glass. In novel melt-derived "1393" Bioactive glass $\left(53 \mathrm{SiO}_{2}, 6 \mathrm{Na}_{2} \mathrm{O}, 12 \mathrm{~K}_{2} \mathrm{O}, 5 \mathrm{MgO}, 20 \mathrm{CaO}\right.$, and $4 \mathrm{P}_{2} \mathrm{O}_{5}$ wt \%) with $\mathrm{CaO}$ was doped by $\mathrm{ZrO}_{2}$ for and were melted at $1400^{\circ} \mathrm{C}$ in alumina crucibles in electric furnace with air as furnace atmosphere. Bioactivity of these samples were analysed by put in the SBF for different time periods. Hydroxy Carbonate Apatite layer was developed and identiûed by FTIR, XRD and SEM. Chemical durability was also determined by weight loss method. Density of the samples were determined and found to increase significantly with increasing amount of (0-2 wt \%) zirconia, reason is due to replacement of lighter element of $\mathrm{CaO}$ has been replaced by heavier element $\mathrm{ZrO}_{2}$. Finally, this investigation clearly concluded that $\mathrm{ZrO}_{2}$ substituted bioactive glass would be potential biomaterials for biomedical applications.
\end{abstract}

Keywords: Bio-active glasses, Simulated body fluid, XRD, SEM, FTIR, pH, Chemical durability, Density.

\section{INTRODUCTION}

Ceramics which are used for filling and rebuilding of non-healing bone defects and for healing of damaged or diseased parts of the muscular-skeletal system is termed as bio ceramics'. Bioinert (alumina, zirconia), bioactive (hydroxyapatite, glass, and glass-ceramics), resorbable (tricalcium phosphate) or porous for tissue in growth (hydroxyapatite-coated metals, alumina) may be used in the bio ceramic composites ${ }^{2}$. Several types of bioactive glasses are developed over past years. Bioactive glasses (BG) have been known for their bioactive properties and their aptitude to form a strong bond to bone by formation of hydroxyapatite surface layer ${ }^{3}$. Bioactive glasses (BGs) such as "45S5 Bio-glass" ${ }^{\circledR "}\left(45 \mathrm{SiO}_{2}, 24.5 \mathrm{CaO}, 24.5 \mathrm{Na}_{2} \mathrm{O}, 6\right.$ $\mathrm{P}_{2} \mathrm{O}_{5}$ wt \%) and "1393" (53 $\mathrm{SiO}_{2}, 6 \mathrm{Na} 2 \mathrm{O}, 12 \mathrm{~K}_{2} \mathrm{O}, 5$ $\mathrm{MgO}, 20 \mathrm{CaO}$, and $4 \mathrm{P}_{2} \mathrm{O}_{5}$ wt \%) compositions have been widely used for bone tissue engineering applications ${ }^{2,4}$. Hench et al., examined the in vitro bonding mechanism with synthetic material 
because of the chemical reactions taking place over glass surface. These chemical reactions strongly help the implants to bond with the bone tissues; hence one can replace the diseased or damaged part of the human bone ${ }^{5}$. Many glass compositions have been developed by doping therapeutically active ions such as strontium, zinc, magnesium, fluoride and cobalt in silicate glass system have been discovered in the past ${ }^{6-9}$. Several researches are going on for preparation and characterization of glasses and glass-ceramics, doped with some ions such as Zr, Li, Fe, Ti, K, Zn, Sr and Mg because of their unique effect on differentiation, osteoblastic cell proliferation and thus bone mineralization ${ }^{10-15}$. The $\mathrm{ZrO}_{2}$ substituted is widely used as a substrate in hard tissue applications due to its excellent strength and fracture toughness ${ }^{16}$. It was discovered from the reaction product obtained after heating gems by the German chemist Martin Heinrich Klaproth in $1789^{17}$. Several research articles have suggested that zirconia has good chemical and dimensional stability, mechanical strength and toughness and it is also biologically inert ${ }^{18}$. Many study have shown that the compressive strength of $\mathrm{ZrO}_{2}$ is relatively higher than porous $\mathrm{HA}$ and ZA20 (20 wt. $\% \mathrm{Al}_{2} \mathrm{O}_{3}$ added TZP) ceramics. In vitro evaluation has also shown that $\mathrm{ZrO}_{2}$ is not cytotoxic ${ }^{19-21}$. Vyas et al.,22-27 in an earlier investigation had also shown that the addition of cobalt oxide and nickel oxide up to $0-2.0$ wt $\%$ in $45 S 5$ glass (BG) and glassceramic (BGC) has resulted an increase physicomechanical properties and bioactivity of their samples due to formation $\mathrm{Co}-\mathrm{O}-\mathrm{Si}$ and $\mathrm{Ni}-\mathrm{O}-\mathrm{Si}$ bonds. Tripathi et al., ${ }^{28}$ have also found the characterization of $\mathrm{Li}_{2} \mathrm{O}, \mathrm{CaO}, \mathrm{Al}_{2} \mathrm{O}_{3}, \mathrm{P}_{2} \mathrm{O}_{5}, \mathrm{SiO}_{2}$ glasses as bioactive material and all the elastic moduli values were establish to increase with the increasing in $\mathrm{Al}_{2} \mathrm{O}_{3} / \mathrm{Li}_{2} \mathrm{O}$ ratio.

In the current investigation an endeavour has been made to study the construct of zirconia doping in silica-based bioactive glass and to verify its bioactivity and other characteristics.

\section{MATERIAL AND METHODS}

\section{Preparation of glass}

For the source of $\mathrm{SiO}_{2}{ }^{15}, \mathrm{Na}_{2} \mathrm{O}, \mathrm{CaO}, \mathrm{K}_{2} \mathrm{O}$, $\mathrm{P}_{2} \mathrm{O}_{5}$ and $\mathrm{MgO}$, Fine grained quartz, anhydrous sodium carbonate, anhydrous calcium carbonate , Potassium Carbonate, ammonium dihydrogen orthophosphate and Magnesium Carbonate respectively were used ${ }^{4}$. The $\mathrm{ZrO}_{2}$ is available as it is and was added for preparation of bioactive glasses. All the batch materials were of analytical grade chemicals and were used without further purification. The weighed batches were mixed properly with the help of mortar and pestle. Before mixing the mortar and pestle were cleaned thoroughly and allowed to dry properly. After thorough mixing of batch materials were kept in alumina crucible and placed in an electric furnace. The furnace temperature was set to $1400^{\circ} \mathrm{C}$ and the duration to reach $1400^{\circ} \mathrm{C}$ was set to $3 \mathrm{~h}$ and after reaching $140^{\circ} \mathrm{C}$ the steady state was maintained for more 3 hours. After melting the prepared bioactive glass samples were poured into moulds and were directly transferred to a regulated muffle furnace at the temperature of $500^{\circ} \mathrm{C}$ for annealing. The muffle furnace was left to cool to room temperature after $1 \mathrm{~h}$ Annealing is done to remove the internal stress after the glasses are formed.

\section{Simulated Body Fluid (SBF)}

Kokubo and his teams developed Simulated Body Fluid (SBF) which has similar inorganic ion concentrations to those of human extracellular fluid ${ }^{22,29-31}$. The ion concentrations of SBF are given on Table. 2 .

\section{Procedure}

1. The $\mathrm{HCl}$ available in the laboratory is of 11.6 N. So it was diluted to $1 \mathrm{~N}-\mathrm{HCl}$ by the following formula.

$$
\mathrm{N}_{1} \mathrm{~V}_{1}=\mathrm{N}_{2} \mathrm{~V}_{2}
$$

Where $\mathrm{N}_{1}, \mathrm{~N}_{2}=$ Normality of $1^{\text {st }}$ and $2^{\text {nd }}$ solution respectively

$V_{1}, V_{2}=$ Volume of $1^{\text {st }}$ and $2^{\text {nd }}$ solution respectively

We have taken $100 \mathrm{ml}$ distilled water and we need to find out how much $\mathrm{HCl}$ of $11.6 \mathrm{~N}$ is required to be mixed with it to get $1 \mathrm{~N}-\mathrm{HCl}$ solution.

$$
\begin{aligned}
& 11.6 \times V_{1}=1 \times 100 \\
& \Rightarrow V_{1}=8.62 \mathrm{ml}
\end{aligned}
$$

So $8.62 \mathrm{ml}$ of $11.6 \mathrm{~N} \mathrm{HCl}$ was mixed with $100 \mathrm{ml}$ of distilled water to get $1 \mathrm{~N}-\mathrm{HCl}$.

2. $700 \mathrm{ml}$ of distilled water is poured into magnetic stirrer. 
3. The 1 to 5 materials mentioned in the table 2 were added one by one.

4. The $1 \mathrm{~N}-\mathrm{HCl}$ was added to the above mixture of about $20 \mathrm{ml}$ and $\mathrm{p}^{\mathrm{H}}$ was maintained to be 2.0/2.5.

5. Then the material numbered 7-8 were added one by one slowly.

6. Finally the tris-buffer was added very slowly. Then $\mathrm{HCl}$ was added and the $\mathrm{p}^{\mathrm{H}}$ was adjusted to be within 7.2/7.25.

Thus, SBF solution was prepared which was used forevaluation of bioactivity of artificial materials in vitro.

\section{Characterization}

Using the XRD, crystalline phases present in before and after SBF treated glass samples were identified. The samples were ground to $751 / 4 \mathrm{~m}$ and subjected to XRD using RIGAKU-Miniûex II diffractometer of range between $20^{\circ}$ and $80^{\circ}$. Fourier trans-form infrared (FT-IR) spectrometer (VARIAN scimitar 1000, USA) range was used to investigate the functional groups present in bio-glass samples in the range of $4000-400 \mathrm{~cm}^{-1}$. The surface morphology of bioactive glass samples was analysed by SEM (Inspect S50, FEI) before and after SBF behaviour.

\section{In vitro bioactivity test}

In vitro test was performed to examined the bioactivity of all samples by immersing $0.5 \mathrm{~g}$ of each samples in $50 \mathrm{ml}$ of SBF solution in a plastic box and incubated at $37.5^{\circ} \mathrm{C}$ in a static condition for 2, 5, 7, 15 and 31 days. $\mathrm{pH}$ was also measured using Universal Biomicroprocessor $\mathrm{pH}$ meter calibrated with buffer solutions of $\mathrm{pH} 4.00$ and 7.00 at room temperature. $\mathrm{pH}$ values have been recorded during above given time periods. The surface morphology of bioactive glass samples was analysed by SEM (Inspect S50, FEI) before and after SBF behaviour. The glass powders $(1 \mathrm{~g})$ were hard-pressed (load of $10 \mathrm{MPa}$ ) into pellet forms in a hand pelletizer machine using an evocable die to produce discs of $10 \mathrm{~mm}$ in diameter. The carboxymethyl cellulose (CMC) was used as a binder for making pellets. The glass pellets were put in SBF $(10 \mathrm{ml})$ for 15 days at $37.5^{\circ} \mathrm{C}$. Samples were coated with gold before SEM analysis.

\section{Density measurement}

The density of samples was measured by Archimedes principle at room temperature. For immersing the samples into water thin copper wire was used. The density was determined from the following equation:

$$
\text { Density }=(\mathrm{Ma} /(\mathrm{Ma}-\mathrm{Mw}))^{\star} 0.988
$$

Ma Mass in air and Mw is the Mass in water.

The measurements were carried out in triplicate.

\section{Weight loss measurement}

The solubility of bioactive glasses was finding by measuring weight loss in SBF at $37.5^{\circ} \mathrm{C}$ in the incubator. With the help of 500 grit polishing papers the samples were polished. Then they were washed in acetone for a minute and were placed in small plastic containers which contain SBF. On various days, the samples were taken out and with the help of tissue excess moisture was removed. Then the samples are weighted. The percentage changes in weight loss were directly correlated to glass corrosion or solubility in SBF. The amount of weight loss was calculated using the following equation:

$$
\text { Weight loss }(\mathrm{mg} / \mathrm{g})=\left(\mathrm{W}_{\mathrm{i}}-\mathrm{W}_{\mathrm{f}}\right) / \mathrm{W}_{\mathrm{i}}
$$

Where $W_{i}$ is the initial weight of the specimen and $W_{f}$ the weight on different days

\section{RESULT AND DISCUSSION}

\section{FTIR Absorbance Spectrometric Investigation of bioactive glass}

Figure.1 shows the FT-IR absorbance spectra of glass samples before put into SBF solution. From Fig.1 it was trend that G-1 and G-2 are showing almost same peak i.e. at wave number $1338.54384 \mathrm{~cm}^{-1}$ respectively. Another peak at 1031 and $945 \mathrm{~cm}^{-1}$ are shown by G-1 and G-2. From the infrared absorption band table we can see that these peaks are referring to - $\mathrm{O}-\mathrm{Si}$ - bond and -Si-Pbond $^{15}$. The rest three glasses are showing peaks in the range 1562, 1556 and 1558, 1338 and 945, 943, $947 \mathrm{~cm}^{-1}$. The $1338 \mathrm{~cm}^{-1}$ wave number corresponds to $\mathrm{P}=\mathrm{O}$ bond $^{32-38}$. The wave number $1556 \mathrm{~cm}^{-1}$ corresponds to -Si-P- bond ${ }^{39}$. The FTIR spectra peaks of G-2, G-3, G-4 and G-5 samples 
have the same behaviour of G-1 with small change in the peaks intensities as shown in the Fig.1. The glasses doped with Zirconia are not showing remarkable changes in the FTIR absorption spectral characteristics.

In vitro bioactivity by FTIR Absorbance Spectrometric The FT-IR absorbance spectral bands of the glasses before and after immersion in SBF for different days such as 2, 5, 7, 15, and 31 days were shown in Fig. 2, 6. The increased in the intensity of absorption band is due to increase in molecular concentration of species on the surface of the glasses after soaking into SBF with time ${ }^{40,41}$.

The FTIR analysis of G-1 before and after drenched into SBF solution for 2, 5, 7, 15 and 31 days were presented in Fig. 2 . The new bands were establish to come out after soaking into 2 days in SBF solution and the corresponding wave numbers are $3745,1558,738 \mathrm{~cm}^{-1}$. The FTIR absorbance spectral band at 738 corresponds to $\mathrm{Si}-\mathrm{O}-\mathrm{Si}$ symmetric stretch of tetrahedral non -bridging oxygen atoms ${ }^{15}$. The major bands at about 1558 are credited to Si-P bond. On 15th day and $31^{\text {st }}$ day peaks are found out at $3184 \mathrm{~cm}^{-1}$ which corresponds to $-\mathrm{OH}$ group (associated). The $1296 \mathrm{~cm}^{-1}$ wave number corresponds to $\mathrm{P}=\mathrm{O}$ bond. The band corresponds to wave number $3745 \mathrm{~cm}-1$ belongs to hydroxyl group (O-H stretch (free) $)^{42}$. This long duration of the sample soaked into SBF shows small decrease in the intensities of the bands which is the result of formation of hydroxyl apatite (HA) layer ${ }^{43}$

Figure. 3 depict it the FT-IR analysis of G-2 bothe before, after drenched into SBF solution for $2,5,7,15$ and 31 days. On $5^{\text {th }}$ days of soaking the prominent wave numbers are obtained at 3136 , 1552, 1338, $1028 \mathrm{~cm}^{-1}$. The 1552 corresponds to Si-P bond. Here a new peak was obtained corresponding to $1338 \mathrm{~cm}^{-1}$ wave number which is associated with $\mathrm{Zr}-\mathrm{OH}$ bonding ${ }^{37,38}$. This is because bio glass is doped with zirconia. The band corresponding to wave number $1028 \mathrm{~cm}^{-1}$ is Si-O-Si stretching bond ${ }^{15}$. The bands at $652 \mathrm{~cm}^{-1}$ correspond to (carbonate) $\mathrm{C}-\mathrm{O}$ stretching mode. The wave number $3136 \mathrm{~cm}^{-1}$ is 31 days corresponds to $\mathrm{OH}$ group (associated). This long duration of the sample soaked into SBF shows small decrease in the intensities of the bands which is the result of formation of hydroxyl corbonate apatite (HA) layer ${ }^{43}$.

Figure. 4 depicted the FT-IR analysis of G-3 before and after drenched it into SBF for 2, 5, 7, 15 and 31 days. On $5^{\text {th }}$ days of soaking, the prominent wave numbers are obtained at wave number 3745, 3136, 2553, 2158, 1558, 1338, 1016, $652 \mathrm{~cm}^{-1}$ respectively. The peak obtained at 1338

Table.1: Composition of base and doped glass

\begin{tabular}{lccccccc}
\hline $\begin{array}{l}\text { Glass } \\
\text { sample } \\
\text { Composition }\end{array}$ & $\mathrm{SiO}_{2(\mathrm{wt} \%)}$ & $\mathrm{Na}_{2} \mathrm{O}_{(\mathrm{wt} \%)}$ & $\mathrm{K}_{2} \mathrm{O}_{(\mathrm{wt} \%)}$ & $\mathrm{P}_{2} \mathrm{O}_{5(\mathrm{wt} \%)}$ & $\mathrm{MgO}_{(\mathrm{wt} \%)}$ & $\mathrm{CaO}_{(\mathrm{wt} \%)}$ & $\mathrm{ZrO}_{2(\mathrm{wt} \%)}$ \\
\hline $\mathrm{G}-1$ & 53 & 6 & 12 & 4 & 5 & 20.0 & 0.0 \\
$\mathrm{G}-2$ & 53 & 6 & 12 & 4 & 5 & 19.5 & 0.5 \\
$\mathrm{G}-3$ & 53 & 6 & 12 & 4 & 5 & 19.0 & 1.0 \\
$\mathrm{G}-4$ & 53 & 6 & 12 & 4 & 5 & 18.5 & 1.5 \\
$\mathrm{G}-5$ & 53 & 6 & 12 & 4 & 5 & 18.0 & 2.0 \\
\hline
\end{tabular}

Table. 2: Ion concentration (m M/liter) of SBF

\begin{tabular}{lllllllll}
\hline Ions & $\mathrm{Na}^{+}$ & $\mathrm{K}^{+}$ & $\mathrm{Mg}^{2+}$ & $\mathrm{Ca}^{2+}$ & $\mathrm{HCO}_{3}^{-}$ & $\mathrm{HPO}_{4}^{2-}$ & $\mathrm{SO}_{4}^{2-}$ & $\mathrm{Cl}^{-}$ \\
\hline SBF & 142.0 & 5.0 & 1.5 & 2.5 & 4.2 & 1.0 & 0.5 & 147.8 \\
WBC & 142.0 & 5.0 & 1.5 & 2.5 & 27.0 & 1.0 & 0.5 & 103.0 \\
\hline
\end{tabular}


is corresponds to $\mathrm{Zr}-\mathrm{OH}$ bonding ${ }^{44,45}$. This is because bio glass is doped with zirconia. The band corresponding to wave number $1016 \mathrm{~cm}^{-1}$ is $\mathrm{Si}-\mathrm{O}-\mathrm{Si}$ stretching bond ${ }^{15}$. The wave number of $1558 \mathrm{~cm}^{-1}$ is linked with Si-P bond. The bands at 652 and 2553 $\mathrm{cm}^{-1}$ are correspond to (carbonate) C-O stretching mode. The wave number at 3136 and $3745 \mathrm{~cm}^{-1}$ are corresponds to $\mathrm{OH}$ group (associated) $\mathrm{OH}$ group (Free) respectively. This long duration of the sample soaked into SBF shows small decrease in the intensities of the bands which is the result of formation of hydroxyl carbonate apatite (HA) layer ${ }^{43}$.

Figure. 5 depicted the FTIR analysis of G-4 before and after drenched it into SBF solution for $2,5,7,15$ and 31 days. On $15^{\text {th }}$ days of soaking, the prominent wave numbers obtained are at 3348 , $1629,1558,1398,1037,628 \mathrm{~cm}^{-1}$. The band corresponding to wave number 1037 is $\mathrm{Si}-\mathrm{O}-\mathrm{Si}$ stretching bond ${ }^{15}$. Here the peak obtained at $1398 \mathrm{~cm}^{-1}$ wave number is corresponds to $\mathrm{Zr}-\mathrm{OH}$ bonding ${ }^{44,45}$. This is because bio glass is doped with zirconia. The wave number of $1558 \mathrm{~cm}^{-1}$ is associated with Si-P bond. The bands at $628 \mathrm{~cm}^{-1}$ corresponds to (carbonate) $\mathrm{C}-\mathrm{O}$ stretching mode. The wave number at $3136 \mathrm{~cm}^{-1}$ corresponds to $\mathrm{OH}$ group (associated). This long duration of the sample soaked into SBF shows small decrease in the intensities of the bands which is the result of formation of hydroxyl carbonate apatite (HA) layer ${ }^{43}$.

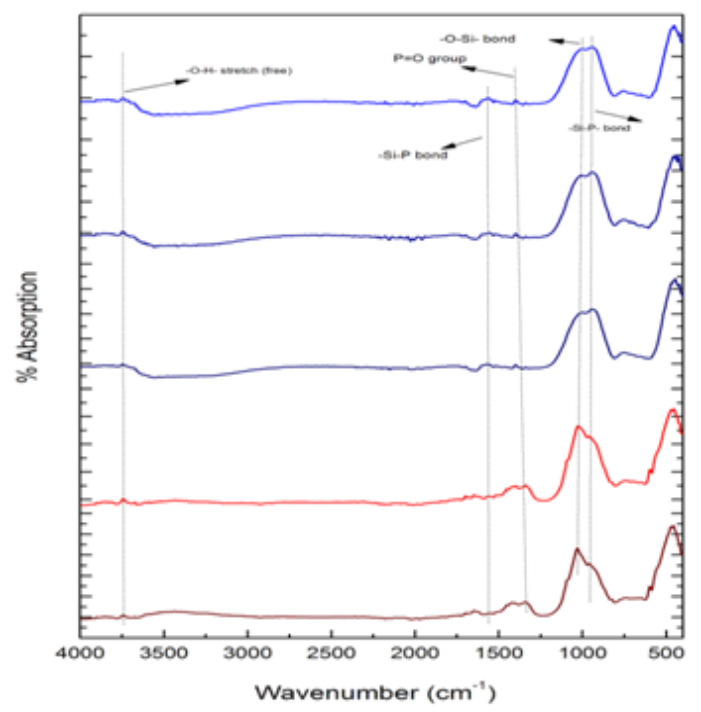

Fig. 1. FTIR Absorbance Spectrometric of glass before immersion into SBF
Figure. 6 depicted the FTIR analysis of G- 5 before and after drenched it into SBF solution for 2, 5, 7, 15 and 31 days. The G-3 sample has a peak at wave number $1028 \mathrm{~cm}^{-1}$ which corresponds to $\mathrm{Si}-\mathrm{O}-\mathrm{Si}$ symmetric stretching. On $15^{\text {th }}$ day of soaking, the prominent wave numbers obtained are at wave number $3290,1629,1558,1398,1037$, $628 \mathrm{~cm}^{-1}$ respectively. The band corresponding to wave number 1037 is $\mathrm{Si}-\mathrm{O}-\mathrm{Si}$ stretching bond ${ }^{15}$. Here the peak obtained at $1398 \mathrm{~cm}^{-1}$ wave number is corresponding to $\mathrm{Zr}-\mathrm{OH}$ bonding ${ }^{44,45}$. This is because bio glass is doped with zirconia. The wave number of $1629 \mathrm{~cm}^{-1}$ is associated with Si-P bond. The wave number of $1558 \mathrm{~cm}^{-1}$ is associated with $\mathrm{P}=\mathrm{O}$ bond. The bands at $628 \mathrm{~cm}^{-1}$ corresponds to (carbonate) $\mathrm{C}-\mathrm{O}$ stretching mode. The wave number at 3290 corresponds to $\mathrm{OH}$ group (associated). This long duration of the sample soaked into SBF shows small decrease in the intensities of the bands which is the result of formation of hydroxyl carbonate apatite (HA) layer ${ }^{43}$.

\section{Bioactivity shown by X-ray diffractometer}

Figure. 7-11 shows the XRD of the glass samples (G-1, G-2, G-3, G-4 and G-5) before and

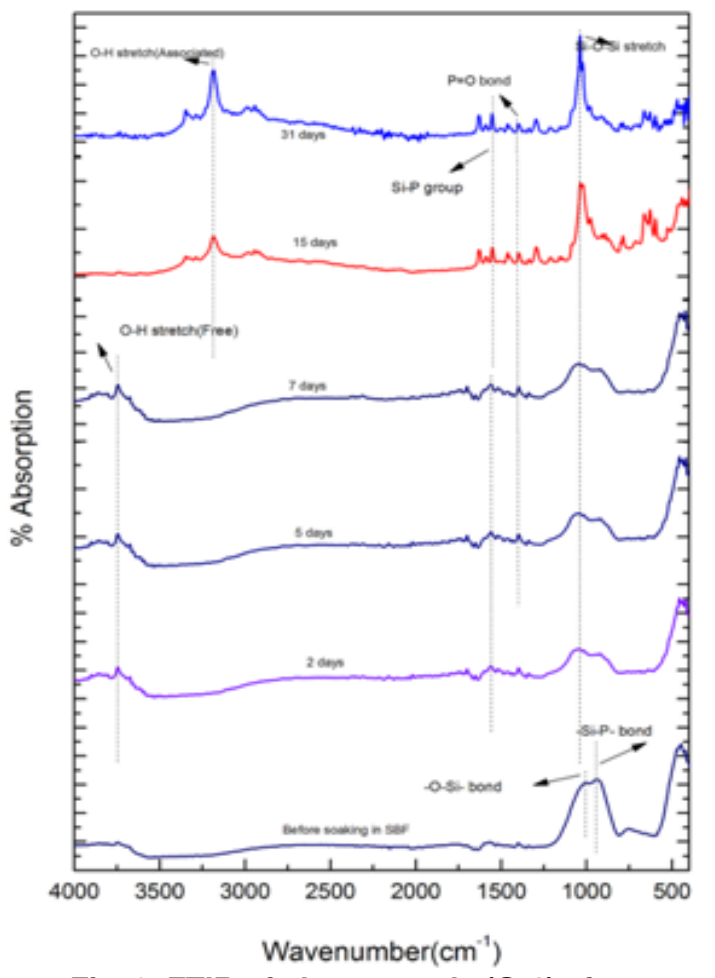

Fig. 2. FTIR of glass sample (G-1) after drenched in SBF 
after putting in SBF for 15 days. The bioactive glasses have shown amorphous nature as there is no sharp peak in the XRD before immersion into SBF solution. The graphs which are drawn after soaking into 15 days in SBF solutions showed broad peaks within the range of $30^{\circ}$ to $35^{\circ}$.

Figure. 7,11 Contains the XRD pattern of Hydroxy Carbonated Apatite (HCA) powder to compare formation of HA layer on the surface of the SBF treated glass samples ${ }^{46}$. The XRD graphs of the SBF treated samples have clearly shown the formation of crystalline HA on their surfaces after putting in SBF for 15 days. From Fig. 7,11 it was observed with increase in Zirconia content the number of peaks becoming more in numbers and broad. The XRD peak located at around $32^{\circ}$ corresponds to Hydroxyapatite [ $\left.\mathrm{Ca}_{10}\left(\mathrm{PO}_{4}\right)_{6}(\mathrm{OH})_{2}\right]$ and the diffraction peaks were matched with the standard PDF\#: $740565^{46}$.

Here it is identified that HA layer is getting formed when zirconia doped 1393 bioactive glasses were immersed into SBF solutions for varying period. The diffraction pattern of all the bioactive glasses showed the Hydroxy Carbonate Apatite crystalline

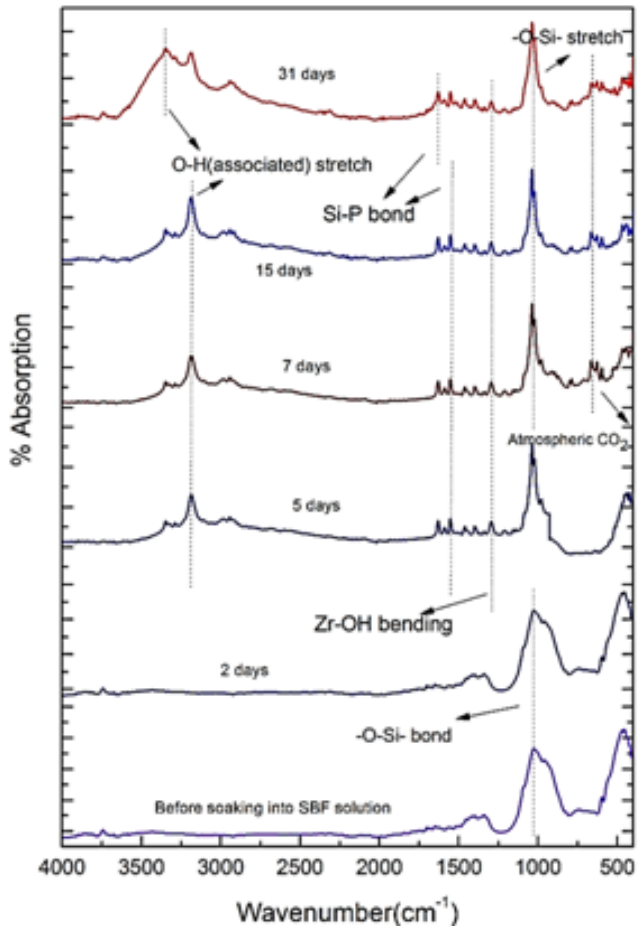

Fig. 3. FTIR of glass sample (G-2) after drenched in Simulated body fluid phases. With increase in zirconia content the peaks which belong to HA were getting sharper.

\section{pH performance in Simulated body fluid}

Variation in $\mathrm{pH}$ values of bioactive glass after drenched into simulated body fluid (SBF) for 2, 5, 7, 15 and 31 days are presented in Fig. 12. It was observed that up to 7 days all glass samples are showing increase in $\mathrm{pH}$ values almost linearly from $\mathrm{pH}$ value 7.3. The $\mathrm{G}-4$ bioactive glass is showing maximum $\mathrm{pH}$ value on $7^{\text {th }}$ day i.e. 9.5. Due to the addition of zirconia there are variations in the $\mathrm{pH}$ values for different samples. The $\mathrm{G}-4$ bioactive glass is showing maximum $\mathrm{pH}$ at the end of $31^{\text {st }}$ day. The G-4 which consists of $1.5 \mathrm{wt} \%$ of Zirconia is showing maximum $\mathrm{pH}$ value. It was found that in all cases the $\mathrm{pH}$ value is decreasing after 7 days and attended a constant value up to $31^{\text {st }}$ days. The increase in $\mathrm{pH}$ values of bioactive glass in SBF is due to release of $\mathrm{Ca}^{2+}$ and $\mathrm{Na}^{+}$ions from the sample surface $22,23,25,26$. The sample number G-4 with higher zirconia content was found to show maximum $\mathrm{pH}$ value may be due to high rate of dissolution as compared to base sample G-1. The incorporation of Zirconia into 1393 glass resulted in an increase in the $\mathrm{pH}$ of SBF. Their high

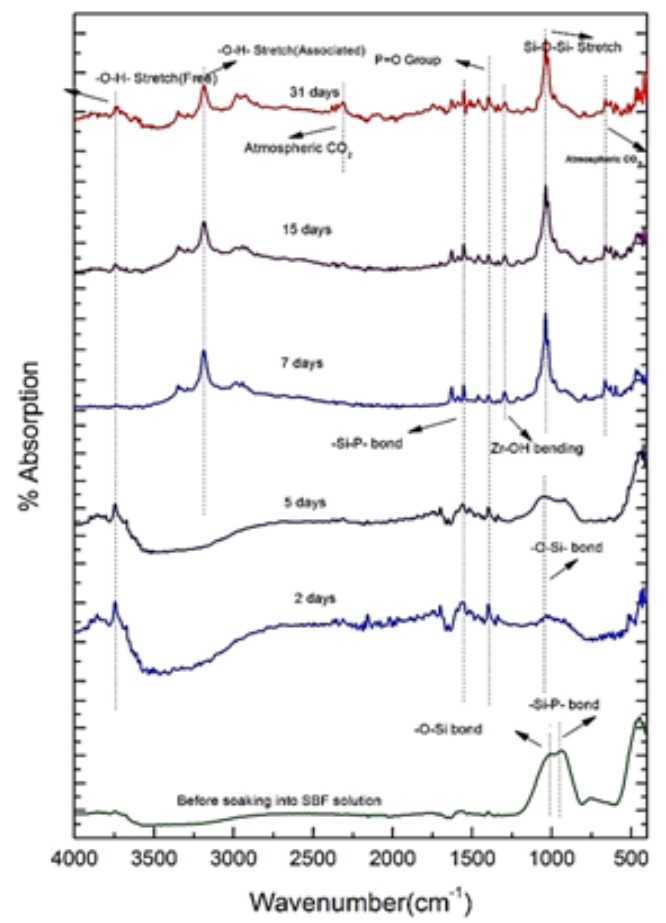

Fig. 4. FTIR of glass sample (G-3) after drenched in Simulated body fluid 
degradation rate leads to a higher $\mathrm{pH}$ value and this agrees to the condition of formation of HA like layer on the surface of the samples with more crystallinity.

\section{Weight loss measurement}

Figure. 13 shows the \% weight losses of glasses are presented in Fig. 13. It was observed that the base glass which is un-doped is showing less weight loss after soaking into SBF solutions. In all cases up to 7 days the weight loss is increasing proportionately with time and after that weight loss is almost constant for respective samples. From the $\mathrm{pH}$ graph the inference is already drawn that the $\mathrm{pH}$ is increasing due to release of $\mathrm{Ca}^{2+}$ and $\mathrm{Na}^{+}$ion into SBF solution that means weight loss in G-4 glass is more which is exactly shown by the weight loss graph. It was found from that up to 7 days the weight loss in G-3, G-4 and G-5 glasses are almost same. That means the glasses with higher content of zirconia are possessing higher rate of dissolution, so $\%$ weight loss is more.

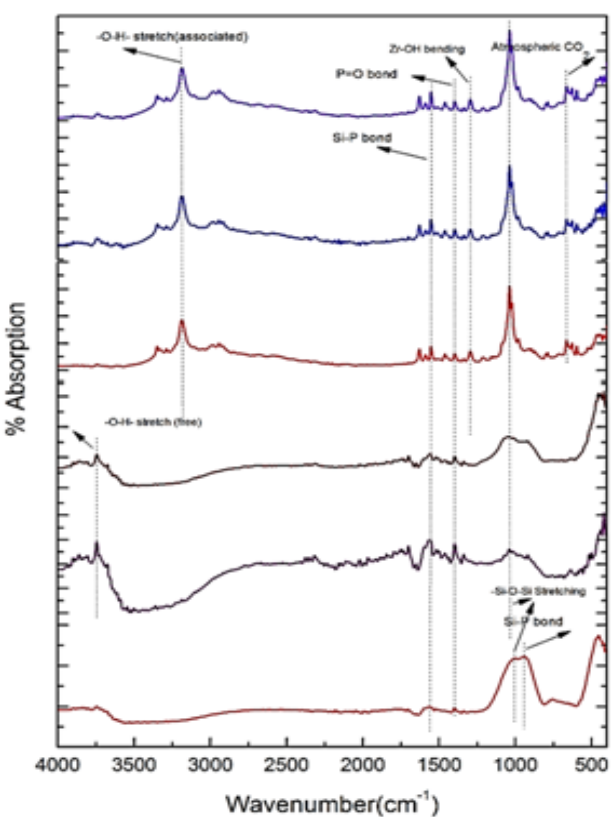

Fig. 6. FTIR of glass sample (G-5) after drenched in Simulated body fluid

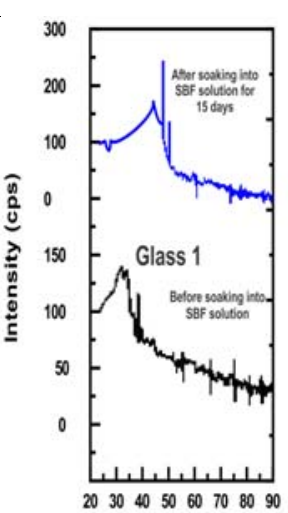

$2 \theta$

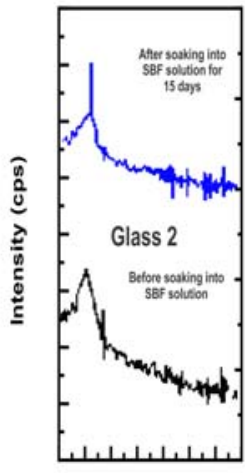

$2 \theta$

Fig.8

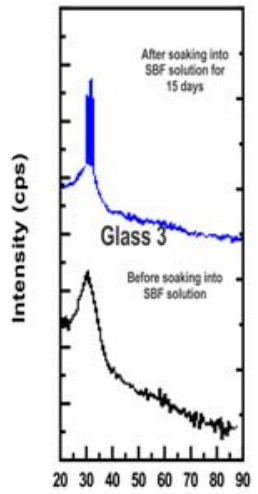

$2 \theta$

Fig.9

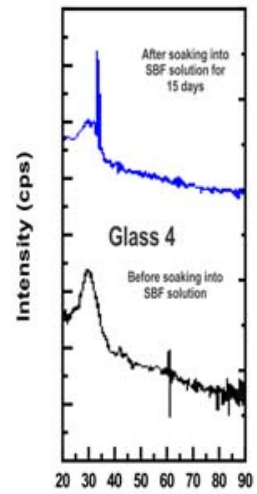

$2 \theta$

Fig.10

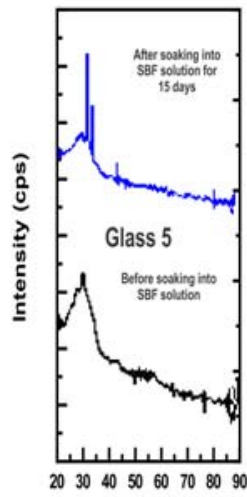

$2 \theta$

Fig.11

Fig. 7-11. XRD of G-1, G-2, G-3, G-4 and G-5 before and after Simulated body fluid for 15 days 


\section{Density Measurement}

Figure. 14 shows the density of $\mathrm{ZrO}_{2}$ doped 1393 glass. It is observed that the density of un-doped sample is found to be $2.44 \mathrm{gm} / \mathrm{cm}^{3}$ and gradually it is increasing up to G-5 which is the highest doped glass ceramic(2.0 wt\% Zirconia). The increase in density is due to replacement of $\mathrm{CaO}$ with $\mathrm{ZrO}_{2}$ which is attributed due to the replacement of a light element (density of $\mathrm{CaO}-3.35 \mathrm{~g} / \mathrm{cm}^{3}$ ) with a heavier one $\left(\mathrm{ZrO}_{2}-5.68 \mathrm{~g} / \mathrm{cm}^{3}\right)$. The rate of increment of density is not same in all the cases as the density of G-3 is increased slightly whereas the rate of increment of density from G-3 to G-4 is more. The total range of density is found to be from $2.44 \mathrm{~g} /$ $\mathrm{cm}^{3}$ to $2.495 \mathrm{~g} / \mathrm{cm}^{3}$. The density of bioactive glass is directly proportional to the solidity of the configuration ${ }^{22,23,25,26}$. Here G-4 and G-5 glass are showing approximately same density which means these materials are suitable for making scaffolds for bone tissue engineering ${ }^{47}$.

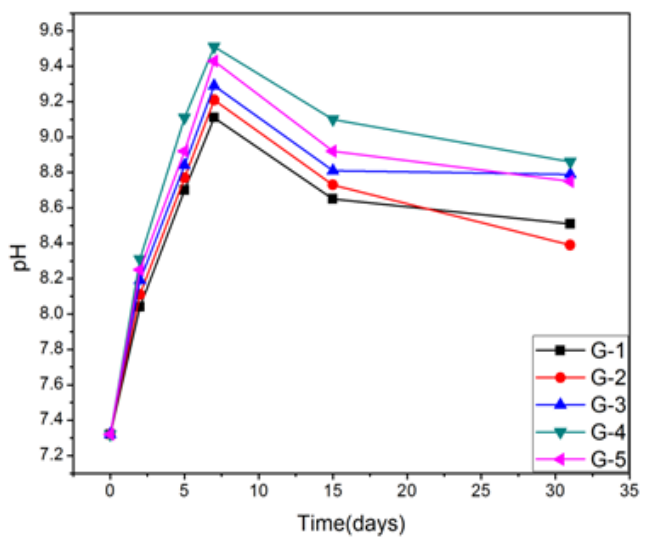

Fig. 12. $\mathrm{pH}$ behaviour of 1393 glass and $\mathrm{ZrO}_{2}$ doped glass sample

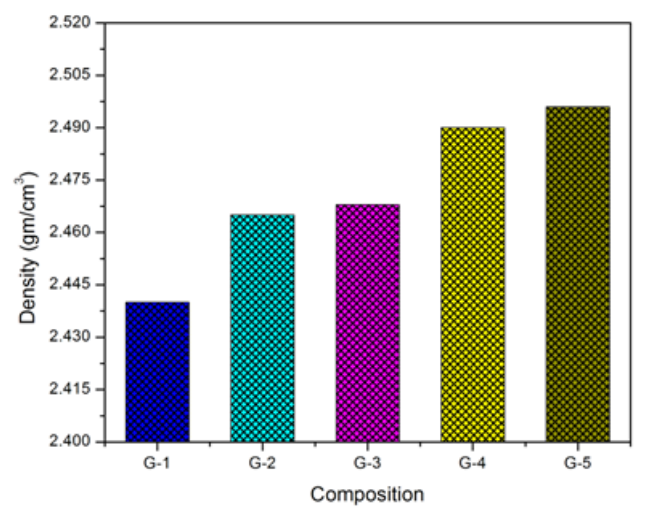

Fig. 14. Density of 1393 bioactive glasses and $\mathrm{ZrO}_{2}$ doped bioactive glass

\section{Surface morphology by SEM}

Figure. 15 and Fig. 16 show the surface morphology of base glass (G-1) and the bioactive glass samples (G-2, G-3, G-4 and G-5) by their SEM images before and after the put in the SBF for 15 days at $37.5^{\circ} \mathrm{C}$. The reflections in the SEM images are showing the glassy surfaces. The SEM images of samples before and after put in SBF shown uniform polycrystalline particle on the surfaces of the glass. These developed crystals on the surface of the glasses are assumed to be $\mathrm{HCA}^{48}$. It is observed that for increasing $\mathrm{ZrO}_{2}$ content, the crystalline phase formed is getting uniform shapes on the glass surfaces and for G-5 the hydroxyl carbonate apatite formed is having needle like structure. It can be concluded that the zirconia doped 1393 glasses can also generate HA like structure on their surfaces after immersion in to SBF solution. Previously It was already found out from the XRD

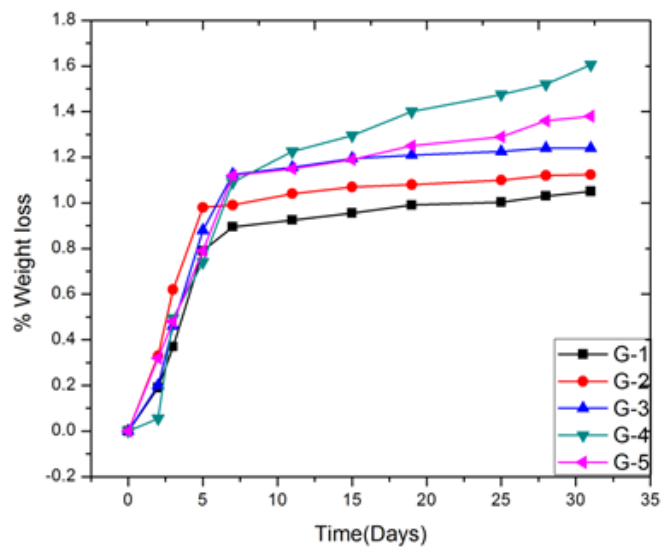

Fig. 13. \% Weight loss of 1393 bioactive glass and $\mathrm{ZrO}_{2}$ doped bioactive glass sample

results and FTIR spectrometry that, the HA layer is getting formed after immersion of glass into SBF for 15 days.

\section{CONCLUSION}

The XRD analysis showed the amorphous nature of the glass and FTIR absorbance spectra, $\mathrm{pH}$ behaviour; XRD and SEM images show the formation of HCA layer on the surface bioactive glasses after putting in SBF. Densities of substituted bioactive glasses are increased with increasing concentration of $\mathrm{ZrO}_{2}$ while their Chemical durability decreased. 
So it can be concluded from the experimental work that all the $\mathrm{ZrO}_{2}$ substituted bioactive glass have shown improved properties. Among all the samples the G-4 glass is the best one as it has shown high $\mathrm{pH}$ value which suggests formation of HCA layer. It can be observed from the FTIR diagram of G-4 that all the bonds are showing prominent peaks and SEM images are also showing impressive results of HA layer formation. The prepared bioactive glasses can be used as for bone tissue engineering applications.
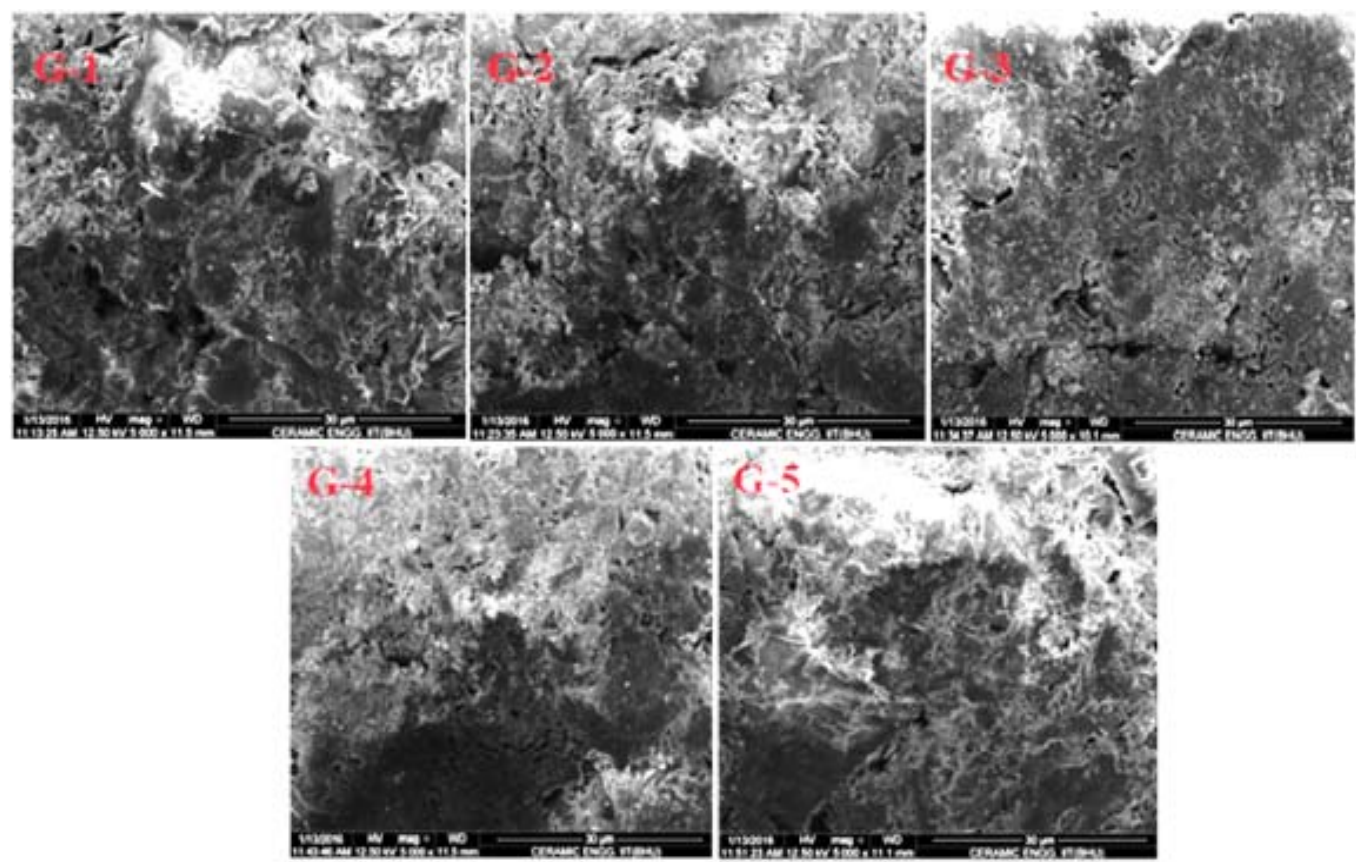

Fig. 15. SEM images of glass before putting into SBF solution
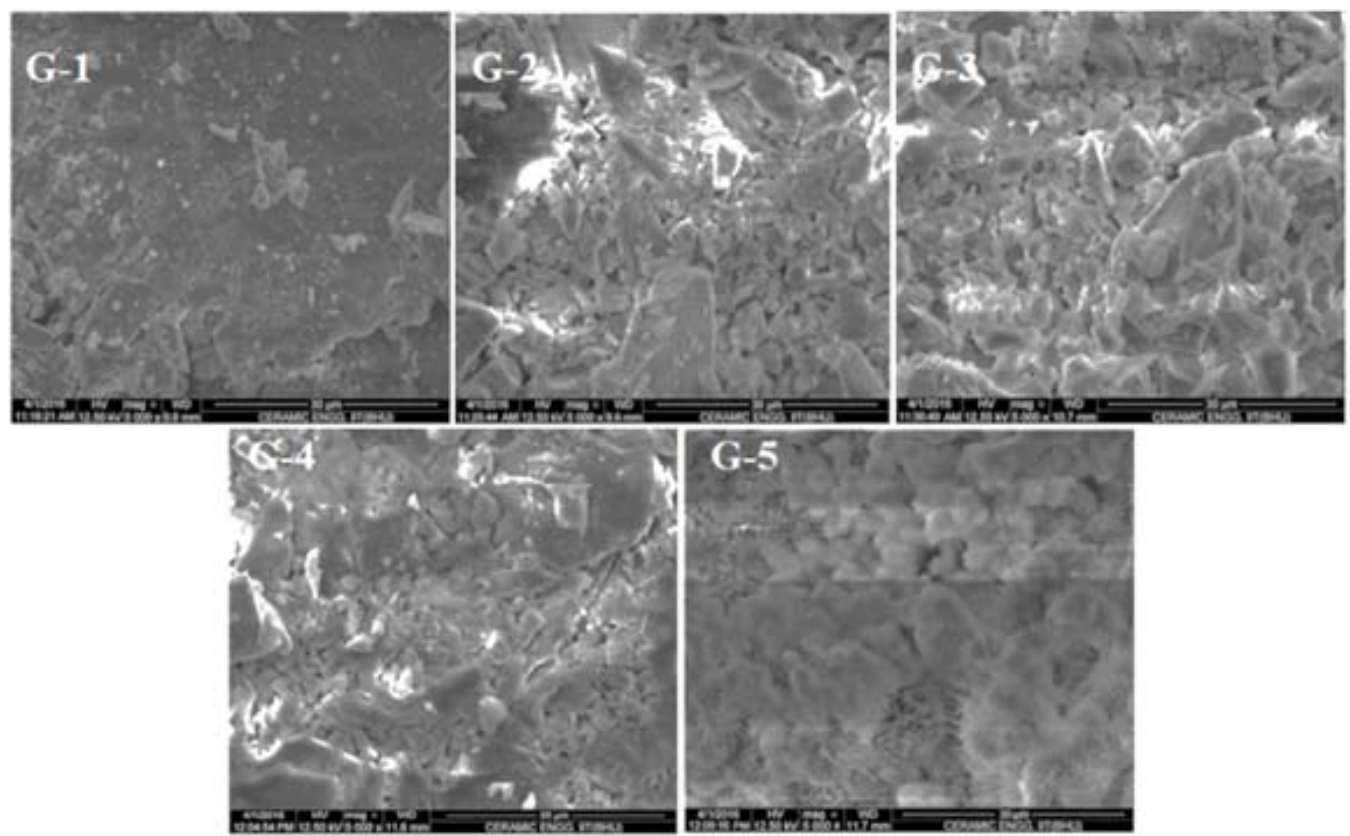

Fig. 16. SEM images of glass after putting into SBF solution 


\section{REFERENCES}

1. Sergey, V. D.; Calcium Orthophosphates as Bio-ceramics: State of the Art., J. Function Biomaterial. 2010, 1, 22-107.

2. Hench, L.L.; Bio-ceramics, J. Am. Ceram. Soc. 1998, 74 (7), 1487-1510.

3. Gerhardt, L.C.; Boccaccini, A. R.; Bioactive Glass and Glass-Ceramic Scaffolds for Bone Tissue Engineering, Materials 2010, 3, 3867-3910.

4. Hoppe. A.; Jokic B.; Janackovic D.; CobaltReleasing 1393 Bioactive Glass-Derived Scaûolds for Bone Tissue Engineering Applications, ACS Appl. Mater. Interfaces 2014, 6, 2865-2877.

5. Ylanen, H. O.; "Bioactive glasses materials properties and applications", Wood head Publishing Limited, Biomaterials, 2011, 6,. 1-288.

6. Heness, G.; Ben-Nissan, B. ; "Innovative bio-ceramics", Mater Forum, 2004, 27, 104-114.

7. Watts, S. J.; O'Donnell, M. D.; Law, R. V.; Hill, R. G.; "Influence of magnesia on the structure and properties of bioactive glasses", J. Non-Cryst. Solid, 2010, 356, 517524.

8. Brauer, D. S.; Karpukhina, N.; O’Donnell M. D.; Law, R. V.; Hill, R. G.; "Fluoridecontaining bio-active glasses: Effect of glass design and structure on degradation $\mathrm{pH}$ and apatite formation in simulated body fluid", Acta-Biomater., 2010, 6, 32753282,

9. Fredholm,Y. C.; Karpukhina, N.; Law, R. V.; Hill, R. G.; "Strontium containing bioactive glasses glass structure and physical properties", J. Non-Cryst. Solids, 2010, 356, 2546-2551,

10. Fatma, H.; ElBatal; Amany ;ElKheshen; Materials Chemistry and Physics, 2008,110, 352-362.

11. O'Donnell, M. D.; Candarlioglu, P. L.; Miller C. A.; Gentleman, E.; Stevens, M. M.; J. Mater. Chem., 2010, 20, 8934-8941.

12. Balamurugan, A.; Rebelo, A.H.; Lemos, A.F.; Rocha, J.H.; Ventura, J.M.; Ferreira, J.M.; Dent Mater.,2008,24,1374-1380

13. Oki, A.; Parveen, B.; Hossain, S; Adeniji, S.; Donahue, H.; J. Biomed Mater Res A. 2004; 69, 216-221.

14. Saboori, A.; Sheikhi, M.; Moztarzadeh, F.;
Rabiee, M.; Hesaraki, S.; Tahriri, M.; AdvApll Ceram. 2009, 108,155-161.

15. Vikash Kumar Vyas; Arepalli Sampath Kumar; HimanshuTripathi; Singh, S.P.; Ram Pyare; Effect of $\mathrm{Cr}_{2} \mathrm{O}_{3}$ Addition on the Bioactivity and Physico-mechanical Properties of $45 S 5$ Bioactive Glass and Glass-Ceramic, International Journal of Engineering Research \& Technology (IJERT) 2014, 3 2, 1-15.

16. Hulbert, S.F.; The use of alumina and zirconia in surgical implants.In: Hench, L.L.; Wilson $\mathrm{J}$; editors. Advanced series in ceramics, 1: An introduction to bioceramics. London: World Scientiûc; 1993.

17. Julian Jones, R.; New trends in bioactive scaffolds: The importance of nanostructure, Journal of the European ceramic society, 2009, 29(7), 1275-1281.

18. Miao, X.; Hu, Y.; Liu, J.; Huang, X.; "Hydroxyapatite coating on porous zirconia", Materials Science and Engineering: 2007, 27(2), 257-261.

19. Sarkar, R.; Banerjee, G.; Ceramic based biomedical implants. Inter. Ceramic, 2010, 2, 98-102.

20. Zhang, S.; Hydroxyapatite Coatings for Biomedical Applications, Advances in Materials Science and Engineering, C.RC Press, 2013, 9,. 469.

21. Ducheyne, P.; Hench, L.L.; Kagan, I.; Martens, A.; Bursens, A.; Mulier, J.C.; Effect of hydroxyapatite impregnations on skeletal bonding of porous coated implants. J. Biomed. Mater. Res.,1980, 14, 225-237.

22. Vyas.V.K. Kumar S.A.; Prasad S.; Singh S.P.; Pyare R.; "Bioactivity and mechanical behavior of cobalt oxide-doped bioactive glass", Bull. Mater. Sci., Indian Academy of Sciences 2015, 38(4), 957-964.

23. Vyas.V.K. Kumar S.A.; Prasad S.; Mohammad E.; Singh S.P.; Pyare R.; "Preparation and Characterization of Cobalt Oxide Doped 45S5 Bioactive GlassCeramics", Innovations in Corrosion and Materials Science, 2015, 5, 86-92,.

24. Vyas.V.K. Kumar S.A.; Singh S.P.; Pyare R.; "Effect of Cobalt Oxide Substitution on Mechanica Behaviour and Elastic 
Properties of Bioactive Glass and GlassCeramics," Trans. Ind. Ceram. Soc., 2016, 75, 1,. 1-8.

25. Vyas.V.K. Kumar S.A.; Singh S.P.; Pyare R.; "Effect of nickel oxide substitution on bioactivity and mechanical properties of bioactive glass," Bull. Mater. Sci., September 2016, 39, 5, 1355-1361.

26. Vyas.V.K.; Kumar S.A.; Singh S.P.; Pyare R.; Ali A.; Prasad S.; Md. Ershad; Srivastava P.; Mallick S.P., "Assessment of nickel oxide substituted bioactive glass-ceramic on in vitro bioactivity and mechanical properties," Boletín de la Sociedad Española de Cerámica y Vidrio, 2016, 69, 12.

27. Vyas.V.K. Kumar S.A.; Singh S.P.; Pyare R, "Destructive and non-destructive behavior of nickel oxide doped bioactive glass and glassceramic", J Aust Ceram Soc, 2017, DOI 10.1007/s41779-017-0110-2.

28. Tripathi H.; Kumar A. S.; Singh S. P.; "Preparation and characterization of $\mathrm{Li}_{2} \mathrm{O}-$ $\mathrm{CaO}-\mathrm{Al}_{2} \mathrm{O}_{3}-\mathrm{P}_{2} \mathrm{O}_{5}-\mathrm{SiO}_{2}$ glasses as bioactive material," Bull. Mater. Sci., 2016,39,2, 365-376.

29. Kokubo, T.; Takadama, H.; "How useful is SBF in predicting in vivo bone bioactivity", Biomaterials, 2006, 27, 2907-2915.

30. Hench, L.L.; Journal of American Ceramic Society, 1998, 81, 1705-1728.

31. Koutsopoulos, S; Synthesis and characterization of hydrox-yapatite crystals: A review study on the analytical methods, J. Biomed. Mater. Res. 2002, 62 (4), 600"612.

32. Montagne, L.; Palavit G.; Mairesse G.; Phys. Chem. Glasses, 1996, 37(5),.206.

33. Brow, R.K.; Tallant, D.R.; Myers, S.T.; Phifer C.C.; J. Non-Cryst. Solids, 1995, 45, 191.

34. Corbridge, D.E.; J. Appl. Chem., 1956, 6,456.

35. Garrigou-Lagrange, C.; Ouchetto M.; Elouadi, B.; Can. J. Chem. 1985, (63), 1436.

36. Gabelica-Robert, M.; Tarte, P.; J. Mol. Struct., 1982, (79), 251.

37. Salim, M.A.; Khattak, G.D.; Sakhawat Hussain, M.; J. Non-Cryst. 1995, $185,101$.

38. Chahine, A.; Et-tabirou, M.; Pascal, J.L.; FTIR and Raman spectra of the $\mathrm{Na}_{2} \mathrm{O}-\mathrm{CuO}-\mathrm{Bi}_{2} \mathrm{O}_{3}$ $-\mathrm{P}_{2} \mathrm{O}_{5}$ glasses, Materials Letters, 2004, 58, 2776-2780.
39. Abel, E. W.; Sabherwal I. H.; Reactions of the silicon-phosphorus bond. Part I. Insertions in trimethy Isilyldi phenyl phosphine, J. Chem. Soc. A, 1968, 1105-1108.

40. Rehman, I.; Karsh, M.; Hench, L.L.; Bonûeld, W.; Analysis of apatite layers on glassceramic particulate using FTIR and FTRaman spectroscopy, J. Biomed. Mater. Res., 2000, 50 (2), 97-100.

41. Filgueiras, M.R.; LaTorre, G.; Hench, L.L.; Solution effects on the surface reactions of three bioactive glass compositions, J. Biomed. Mater. Res,. 1993, 27(12), 1485-1493.

42. Nayak, J. P.; Kumar, S.; J. Bera, "Sol-gel synthesis of bio-glass- ceramics using rice husk ash as a source for silica and its characterization", J. Non-Cryst. Solids, 2010,. 356, 1447-1451.

43. Arepalli S. K.; , Tripathi, H.; Vyas, V. K.; Jain, S.; Suman, S. K.; Ram Pyare; Singh, S.P.; "Influence of barium substitution on bioactivity, thermal and physico-mechanical properties of bioactive glass", Material Science and Engineering (C), 2015, 49, 549-559.

44. Jayakumar, S.; Ananthapadmanabhan, P.V.; Perumal, K.; Thiyagarajan, T.K.; Mishra, S.C.; Su L.T.; Tok, A.I.Y.; J Guo, "Characterization of nano-crystalline $\mathrm{ZrO}_{2}$ synthesized via reactive plasma processing", Materials Science \& Engineering B, 2011, 12,894-899.

45. Sarkar, D.; Mohapatra, D.; Ray, S.; Bhattacharyya S.; Adak, S.; Mitra, $\mathrm{N}$.;"Synthesis and characterization of sol-gel derived $\mathrm{ZrO}_{2}$ doped $\mathrm{Al}_{2} \mathrm{O}_{3}$ nanopowder", Ceramic international, 2007, 33(7),1275-1282.

46. JCPDS Card no. 1994, 9-432,

47. Kansal, I.; Goel A.; Tulyaganov, D.U.; Santos, L.F.; Ferreira, J.M.F.; Structure, surface reactivity and physico-chemical degradation of fluoride containing phospho-silicate glasses, J. Mater. Chem., 2011, 21(22), 8074-8084.

48. ElBatal H.; Azooz, M.; Khalil, E.M.; Soltan Monem A.; Hamdy, Y.; Characterization of some bioglass-ceramics, Mater. Chem. Phys., 2003, 80(3), 599-609. 